\title{
Childhood obesity and hypertension: Should we be alert?
}

Obesity has become a major concern for impending global epidemic. According to WHO, approximately 22 million under 5 children and 155 million children between 5 to 17 years were overweight or obese in 2004 . $^{1,2}$ The prevalence of obesity in affluent school children was found to be $6 \%$ in Chennai, $7.4 \%$ in Delhi and $17.9 \%$ in Dhaka. ${ }^{3,4,5}$ Childhood obesity is associated with several metabolic and endocrine derangements leading to metabolic syndrome, including hypertension. ${ }^{6}$ The prevalence of hypertension among normal school children varies from $1.8-3.5 \%{ }^{7,8,9}$, and which was found significantly higher among Bangladeshi obese children (10.7\%,systolic hypertension and $15 \%$,diastolic hypertension $)^{10}$ and lack of physical activities and intake of rich foods were significantly correlated ${ }^{7,10}$. Obesity leads to hyperinsulinaemia which causes excess renal sodium retention, increased sympathetic activity, growth of vascular smooth muscle, alteration in lipid metabolism and all these favours adiposity, hypertension and cardiovascular diseases. ${ }^{11}$ Age and sex specific BMI, waist circumference (WC) cut-off values and waist-hip circumference are used to identify childhood obesity and the cardiovascular risk factors. The target reference values of waist circumference for children aged 16 years $\&$ older are $<80 \mathrm{~cm}$ (females) and $<94 \mathrm{~cm}$ (males). ${ }^{12}$ Waisthip ratio $>0.8$ (woman) and $>0.9$ (men) is associated with an increased risk insulin resistance and associated diseases. ${ }^{13}$ The high prevalence of childhood obesity and its strong association with hypertension and premature onset of chronic diseases is now a big concern for children. Therefore, it is now important to find out ways to prevent both obesity and hypertension to protect our future generation.

(J Bangladesh Coll Phys Surg 2020; 38: 109) DOI: https://doi.org/10.3329/jbcps.v38i3.47056

\author{
Md Abid Hossain Mollah \\ Professor of Paediatrics, \\ BIRDEM General Hospital, Dhaka
}

\section{References:}

1. World Health Organization. Global strategy on diet, physical activity and health: Obesity and overweight, 2004.

2. Lobstein T, Baur L, Uauy R; IASO International Obesity Task Force. Obesity in children and young people: a crisis in public health. Obes Rev. 2004; 5 Suppl 1, 4-104.

3. Subramanya V, Jayashree R, Rafi M. Prevalence of overweight and obesity in affluent adolescent girls in Chennai in 1981 and 1998. Indian Pediatrics 2003; 40: 332-36.

4. Kapil U, Singh P, Pathak P, Dwivedi SN, Bhasin S. Prevalence of obesity among affluent adolescent school children in Delhi. Indian Pediatrics 2002; 39: 449-52.

5. Mohsin F, Tayyeb S, Baki A, Zabeen B, Sharker S, Begum $\mathrm{T}$, et al. Prevalence of obesity among affluent school children in Dhaka. Mymensingh Med J 2010;19: 627-31.

6. Aggoun Y. Obesity, metabolic syndrome and cardiovascular disease. Pediatr Res 2007; 61: 653-59.

7. Islam MR, Islam LT, Haque SS, Jubayer M, Mollah AH, Ahmed SM et al. Hypertension in school children of Dhaka city and associated risk factors. Mymensingh Med J. 2019 Oct; 28 (4): 849-853. PMID: 31599250

8. Hansen ML, Gunn PW, Kaelber DC. Underdiagnosis of hypertension in children and adolescents. JAMA. 2007; 298:874-879.

9. McNiece KL, Poffenbarger TS, Turner JL, Franco KD, Sorof JM, Portman RJ. Prevalence of hypertension and pre-hypertension among adolescents. J Pediatr. 2007; 150:640-644.

10. Mahbuba S, Mohsin F, Rahat F, Nahar J, Begum T, Nahar N. Descriptive Epidemiology of Metabolic Syndrome Among Obese Adolescent Population. Diabetes \& Metabolic Syndrome: Clinical Research \& Reviews 2018; 12: 369374 .

11. Steinberger J, Daniels SR. Obesity, Insulin resistance, Diabetes and Cardiovascular risk in Children. American Heart Association scientific statement. 2003; 107: 1448-53.

12. Shinomiya M, Ishikawa Y, Shiraj K et al. The significance of waist-hip ratio in obese children. International Journal of Obesity 1990; 14: 135.

13. Caro J. Insulin resistance in obese and non obese man. Journal of Clinical Endocrinology and Metabolism 1991; 73: 692 . 